\title{
STATUS KEBERLANJUTAN PENGELOLAAN EKOSISTEM MANGROVE DI KECAMATANTARUMAJAYA, KABUPATEN BEKASI
}

\author{
(Status of Sustainability Mangrove Ecosystem Management in Tarumajaya District, \\ Bekasi Regency)
}

\author{
Abiyyu Muhammad Haris ${ }^{1}$, Hartrisari Hardjomidjojo² dan Cecep Kusmana ${ }^{3}$ \\ ${ }^{1}$ Ilmu Pengelolaan Sumber Daya Alam dan Lingkungan, Sekolah Pascasarjana, IPB University, \\ Jl. Lingkar Akademik, Kampus IPB Darmaga, Bogor, 16680, Indonesia;e-mail: abiyyumh@gmail.com \\ ${ }^{2}$ Departemen Teknologi Industri Pertanian, Fakultas Teknologi Pertanian, IPB University, \\ Jl. Lingkar Akademik, Kampus IPB Darmaga, Bogor, 16680, Indonesia;e-mail : hartrisari@apps.ipb.ac.id \\ ${ }^{3}$ Departemen Silvikultur, Fakultas Kehutanan dan Lingkungan, IPB University, \\ Jl. Lingkar Akademik, Bogor, 16680, Indonesia;e-mail: ckmangrove.com
}

Diterima 3 Juli 2021, direvisi 19 Oktober 2021, disetujui 19 Oktober 2021

\begin{abstract}
Mangrove ecosystems provide various useful types of products and services to support the life needs of coastal communities. In the management of sustainable mangrove ecosystems, it is necessary to integrate activities in the ecological, economic, and social dimensions as it is known in the concept of sustainable development. This study aims to measure the sustainability status of mangrove ecosystem management in Tarumajaya District, Bekasi Regency. Data analysis is applying RAPFISH with the multidimensional scaling (MDS) method. The results show that the sustainability status of mangrove ecosystem management in Tarumajaya District, Bekasi Regency, obtains a multidimensional index value of $45.79 \%$ with less sustainable status, index value; and the sustainability status in each dimension, is $21.72 \%$ for the ecological dimension (unsustainable), 49.15\% for economic dimension (less sustainable), $40.68 \%$ for social dimension (less sustainable), and $63.68 \%$ for institutional dimension (quite sustainable). The influencing factors for the sustainability of mangrove ecosystem management consist of 16 indicators from the 4 dimensions tested. The results of statistical parameter validation and the results of the Monte Carlo test show that all of the dimension indicators analyzed in the management of sustainability of mangrove ecosystems have a significant role in explaining the diversity of mangrove ecosystems dimensional index value and have a high level of confidence.
\end{abstract}

Keywords: Mangrove ecosystem management, Multidimensional analysis, RAPFISH, Sustainability.

\begin{abstract}
ABSTRAK
Ekosistem mangrove menyediakan berbagai jenis produk dan jasa yang berguna untuk menunjang keperluan hidup penduduk pesisir. Pengelolaaan ekosistem mangrove yang berkelanjutan perlu pengintegrasian antara kegiatan dalam dimensi ekologi, ekonomi, dan sosial. Pencapaian tujuan kebijakan terkait pengelolaan hutan mangrove memerlukan dukungan strategi perencanaan pengelolaan efektif yang dibangun dari berbagai pandangan, pengetahuan dan pengalaman yang bersumber dari para praktisi, peneliti, dan berbagai stakeholders. Penelitian ini bertujuan untuk mengukur status keberlanjutan pengelolaan ekosistem mangrove Kecamatan Tarumajaya, Kabupaten Bekasi. Analisis data menggunakan RAPFISH (Rapid Appraisal for Fisheries) dengan metode multidimensional scaling (MDS). Hasil penelitian menunjukkan bahwa status keberlanjutan pengelolaan ekosistem mangrove Kecamatan Tarumajaya, Kabupaten Bekasi diperoleh nilai indeks multidimensi sebesar 45,79 $\%$ dengan status kurang berkelanjutan, nilai indeks dan status keberlanjutan pada setiap dimensi, yaitu dimensi ekologi 21,72\% (tidak berkelanjutan), dimensi ekonomi 49,15\% (kurang berkelanjutan), dimensi sosial 40,68\% (kurang berkelanjutan), dan dimensi kelembagaan 63,68 \% (cukup berkelanjutan). Faktor-faktor yang berpengaruh terhadap keberlanjutan pengelolaan ekosistem mangrove total berjumlah enam belas indikator dari empat dimensi
\end{abstract}


yang diuji. Hasil validasi parameter statistik dan hasil uji Monte Carlo menunjukkan bahwa keseluruhan indikator dimensi yang dianalisis dalam keberlanjutan pengelolaan ekosistem mangrove memiliki peran yang cukup besar dalam menjelaskan keragaman dari nilai indeks dimensi dan memiliki tingkat kepercayaan yang tinggi.

Kata kunci: Keberlanjutan, analisis multidimensional, RAPFISH, pengelolaan ekosistem mangrove.

\section{PENDAHULUAN}

Ekosistem mangrove memberikan manfaat secara ekologis sebagai penyedia nutrisi, tempat memijah serta mencari makan beberapa biota perairan, melindungi garis pantai dari erosi, menyediakan area pembibitan bagi banyak spesies ikan dan krustasea, mencegah intrusi air laut dan angin kencang, dan penahan gelombang laut; serta manfaat ekonomis antara lain sebagai penyedia berbagai hasil hutan kayu dan jasa ekosistem dan menyediakan tempat untuk area pembibitan mangrove (Giri et al., 2015; Kuenzer et al., 2011; Masood et al., 2015; Sasidhar et al., 2013). Ekosistem mangrove menyediakan berbagai jenis produk dan jasa yang berguna untuk menunjang keperluan hidup penduduk pesisir dan berbagai kegiatan ekonomi, baik skala lokal, regional, maupun nasional serta sebagai penyangga sistem kehidupan masyarakat pesisir (Kusmana, 2014).

Ekosistem mangrove di Kecamatan Tarumajaya, Kabupaten Bekasi diduga rentan terhadap berbagai gangguan, terutama akibat praktik pengelolaan sumber daya laut yang tingkat pengaturannya belum dikelola dengan baik serta letaknya yang berdekatan dengan kawasan industri yang tidak mengindahkan kelestarian lingkungan pesisir. Beberapa hal yang mengancam kegiatan pengelolaan sumber daya pesisir di Kecamatan Tarumajaya, Kabupaten Bekasi adalah perilaku masyarakat yang merusak lahan mangrove seperti penebangan pohon, konversi lahan mangrove menjadi tambak perikanan, dan eksploitasi mangrove. Tujuan pengelolaan ekosistem mangrove berkelanjutan adalah bagaimana menggabungkan antara kepentingan ekologi (konservasi hutan mangrove), ekonomi dan kepentingan sosial (Pramudji, 2011). Pencapaian tujuan kebijakan terkait pengelolaan ekosistem mangrove memerlukan dukungan strategi perencanaan pengelolaan efektif yang dibangun dari berbagai pandangan, pengetahuan dan pengalaman yang bersumber dari para praktisi, peneliti, dan berbagai stakeholders (Patang, 2012).

Kerusakan (degradasi) pada ekosistem mangrove di Kecamatan Tarumajaya, Kabupaten Bekasi harus ditangani secara tuntas dan dikelola secara benar agar fungsinya dapat dimanfaatkan secara optimal bagi sistem penyangga kehidupan dan keberlanjutan tipe-tipe ekosistem lainnya yang sustainabilitasnya berkaitan dengan eksistensi ekosistem mangrove. Peningkatan kinerja pengelolaan ekosistem mangrove di Kecamatan Tarumajaya, Kabupaten Bekasi dapat dicapai melalui penerapan konsep pengelolaan ekosistem mangrove berkelanjutan. Konsep ini didasarkan pada kerangka segitiga pembangunan berkelanjutan (sustainable development triangle) yang menggambarkan bahwa pembangunan berkelanjutan berorientasi pada tiga dimensi keberlanjutan yang saling mendukung dan terkait, yaitu dimensi ekologi, ekonomi, dan sosial (Pattimahu 2010). Penelitian ini bertujuan untuk mengukur status keberlanjutan pengelolaan ekosistem mangrove di Kecamatan Tarumajaya, Kabupaten Bekasi. 


\section{METODE PENELITIAN}

Penelitian dilaksanakan pada bulan Desember tahun 2020 sampai dengan Februari tahun 2021 di Kecamatan Tarumajaya, Kabupaten Bekasi.

Jenis data yang diperlukan dalam penelitian ini adalah data primer dan data sekunder. Kebutuhan data primer diperoleh melalui survei ke lokasi penelitian dengan teknik purposive sampling. Untuk menghimpun dan menggali informasi dan pengetahuan dari informan kunci dilakukan dengan teknik wawancara mendalam (in-depth interview). Wawancara mendalam dilakukan agar peneliti dapat mengumpulkan dan menetapkan skor pada setiap indikator dimensi pengelolaan berkelanjutan (Lampiran 1).

Responden berjumlah 15 orang yang digunakan sebagai informan kunci terdiri dari pengusaha/swasta (2 orang), Dinas Perikanan dan Kelautan Kab. Bekasi (2 orang), Pemerintah Desa dan Kecamatan Tarumajaya (2 orang), Dinas Lingkungan Hidup Kab. Bekasi (2 orang), LSM (2 orang), tokoh masyarakat (3 orang), dan peneliti/ akademisi (2 orang). Data sekunder diperoleh melalui penelusuran dokumen-dokumen yang berkaitan dengan wilayah penelitian meliputi: data statistik kecamatan/desa, data hasil penelitian sebelumnya serta dokumendokumen ilmiah lainnya dari berbagai instansi terkait yang relevan untuk bahan penelitian.

Prosedur analisis data pengelolaan ekosistem mangrove berkelanjutan menggunakan analisis RAPFISH (Rapid Appraisal for Fisheries) dengan pendekatan berbasis multidimensional scaling (MDS) yang dikembangkan oleh Fisheries Center, Univercity of British Colombia (Cissé et al., 2014; Pitcher \& Preikshot, 2001). Konsep dasar MDS adalah proses yang menentukan koordinat posisi tiap obyek dalam suatu peta multi dimensi sehingga jarak antar obyek pemetaan akan sesuai dengan nilai kedekatan dalam input datanya. Bae et al., (2012) menyatakan bahwa ukuran kedekatan antar pasangan obyek berupa nilai kemiripan (similarity) atau nilai ketidakmiripan (dissimilarity).

Penilaian keberlanjutan pengelolaan ekosistem mangrove dengan pendekatan Multidimensional scaling terdiri dari beberapa tahapan, yaitu:

1. Penentuan indikator pengelolaan ekosistem mangrove di Kecamatan Tarumajaya, Kabupaten Bekasi secara berkelanjutan

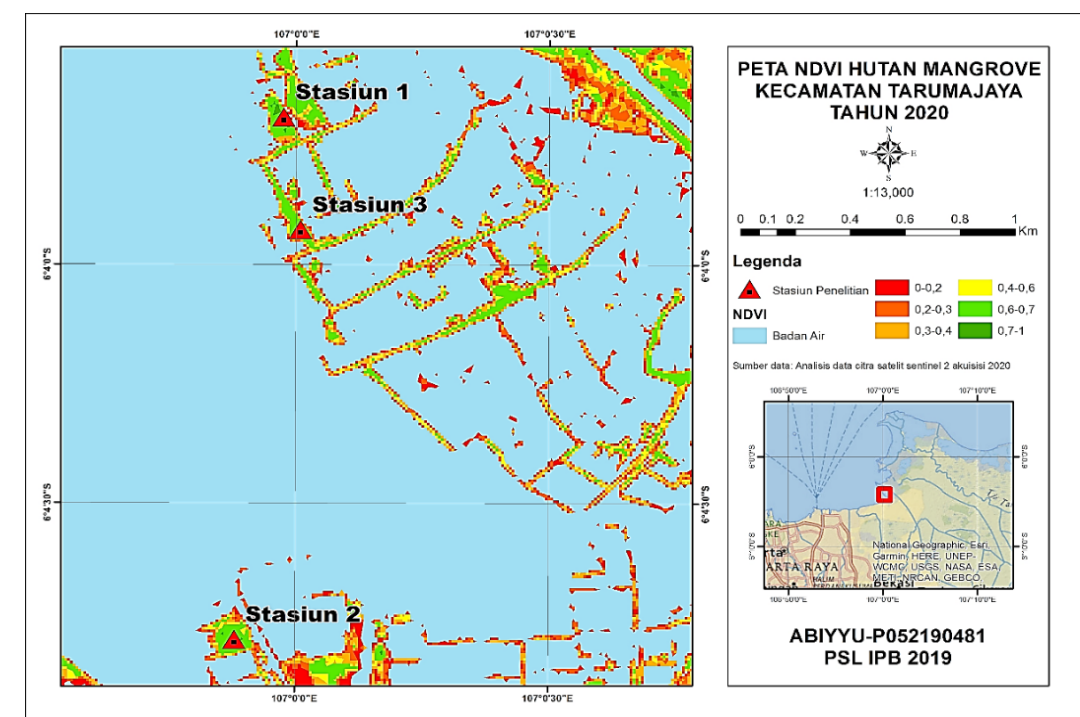

Sumber (Source): Data Primer, diolah (Primary data, processed)

Gambar 1. Peta lokasi penelitian

Figure 1. Research location map. 
untuk masing-masing dimensi (ekologi, ekonomi, sosial, dan kelembagaan). Empat dimensi tersebut terdiri atas 30 atribut yang digunakan untuk mempresentasikan status keberlanjutan mangrove di Kecamatan Tarumajaya, Kabupaten Bekasi.

2. Penilaian setiap indikator (scoring) dalam skala ordinal berdasarkan kriteria keberlanjutan untuk setiap faktor dan informan kunci dari pembuat skor yang mencerminkan kondisi aktual lokasi penelitian.

3. Ordinasi nilai indeks keberlanjutan pengelolaan ekosistem mangrove di Kecamatan Tarumajaya, Kabupaten Bekasi. Indeks keberlanjutan pengelolaan mempunyai rentang antara $0-100 \%$ yang disusun dalam empat kategori.

4. Melakukan analisis Leverage dan analisis Monte Carlo. Analisis Leverage berfungsi untuk menentukan nilai faktor yang berpengaruh terhadap keberlanjutan dimensi pengelolaan. Analisis Monte Carlo berfungsi untuk untuk menguji tingkat kepercayaan nilai indeks total maupun setiap dimensi (Pitcher \& Preikshot, 2001).

\section{HASIL DAN PEMBAHASAN}

\section{A. Hasil}

Berdasarkan hasil pengolahan data terhadap indikator dimensi keberlanjutan pengelolaan ekosistem mangrove di Kecamatan Tarumajaya, Kabupaten Bekasi yang berjumlah 30 indikator, terdiri dari tujuh indikator dimensi ekologi, delapan indikator dimensi sosial, tujuh indikator dimensi ekonomi, dan delapan indikator dimensi kelembagaan (Lampiran 1).

Hasil analisis MDS dengan menggunakan RAPFISH menunjukkan nilai indeks keberlanjutan dimensi ekologi sebesar 21,72\% (tidak berkelanjutan).

Tabel 1. Kategori status keberlanjutan pengelolaan ekosistem mangrove berdasarkan nilai indeks hasil analisis RAPFISH

Table 1. Sustainable status category of mangrove ecosystem management based on index value from RAPFISH analysis

\begin{tabular}{cc}
\hline Nilai Indeks (Index Value) & Kategori (Category) \\
\hline $0-25 \%$ & Tidak berkelanjutan \\
$25-50 \%$ & Kurang berkelanjutan \\
$50-75 \%$ & Cukup berkelanjutan \\
$75-100 \%$ & Berkelanjutan \\
\hline
\end{tabular}

Sumber (Source): Fauzi \& Anna (2005)

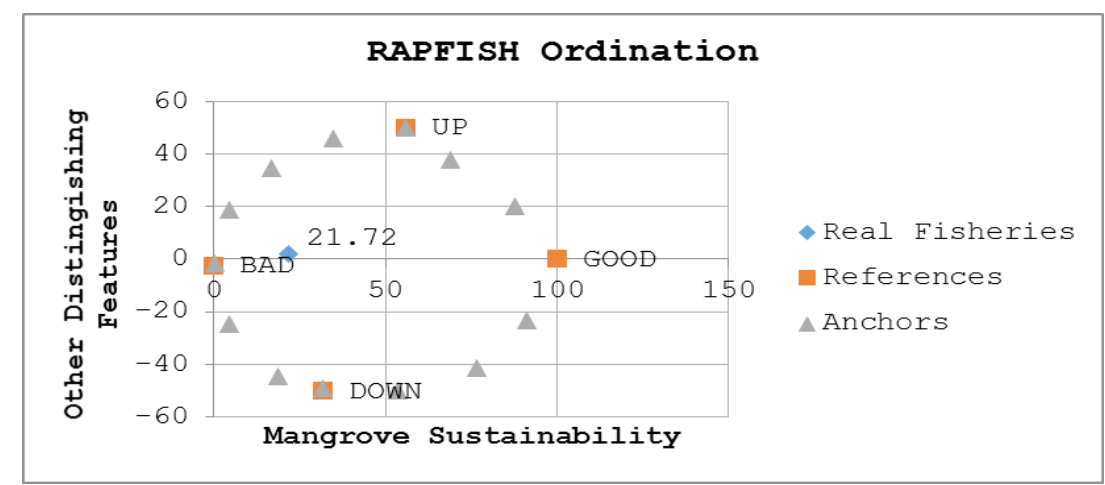

Sumber (Source): Data Primer, diolah (Primary data, processed)

Gambar 2. Indeks keberlanjutan dimensi ekologi

Figure 2. Ecological dimension sustainability index. 
Indikator yang dinilai terhadap keberlanjutan dimensi ekologi ada sebanyak tujuh indikator, yaitu (1) kerapatan mangrove, (2) tutupan mangrove, (3) keanekaragaman mangrove, (4) keragaman fauna mangrove, (5) rehabilitasi ekosistem mangrove, (6) tekanan lahan mangrove, (7) perubahan garis pantai.

Hasil analisis leverage pada dimensi ekologi menunjukkan empat indikator yang sensitif terhadap nilai indeks keberlanjutan dari dimensi tersebut, yaitu (1) rehabilitasi ekosistem mangrove, (2) keanekaragaman mangrove, (3) keanekaragaman fauna mangrove, dan (4) tutupan mangrove.
Berdasarkan hasil analisis MDS menggunakan RAPFISH, nilai indeks keberlanjutan pada dimensi ekonomi adalah 49,15\% (kurang berkelanjutan).

Status keberlanjutan ini ditentukan oleh tujuh indikator yang terdiri dari (1) kontribusi terhadap PDRB (Produk Domestik Regional Bruto), (2) pemanfaatan mangrove oleh masyarakat, (3) pendapatan masyarakat terhadap UMR (Upah Minimum Rata-rata), (4) pendapatan lain, (5) hasil inventarisasi pemanfaatan hutan mangrove, (6) keterlibatan stakeholders, (7) zonasi pemanfaatan lahan mangrove.

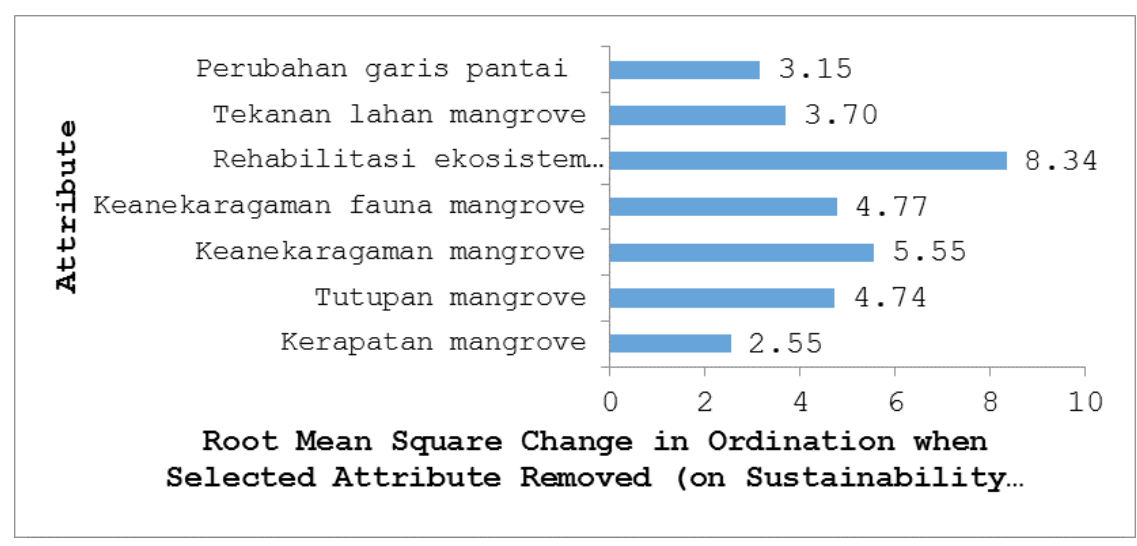

Sumber (Source): Data Primer, diolah (Primary data, processed)

Gambar 3. Hasil analisis leverage (sensitivitas) dimensi ekologi Figure 3. Result analysis of leverage (sensitivity) of ecological dimension.

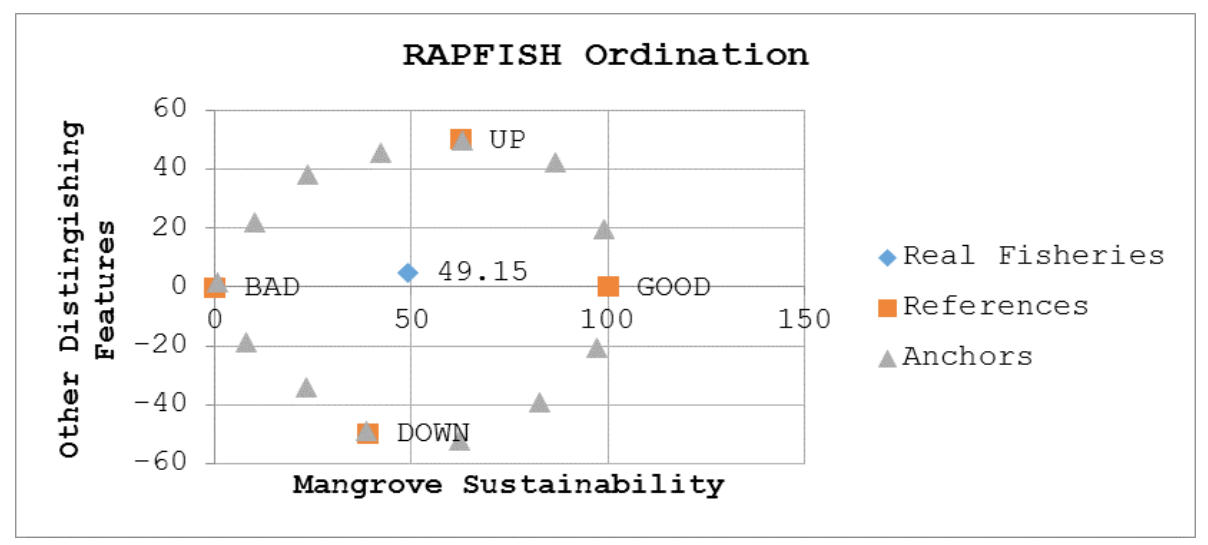

Sumber (Source): Data Primer, diolah (Primary data, processed)

Gambar 4. Indeks keberlanjutan dimensi ekonomi

Figure 4. Economic dimension sustainability index. 


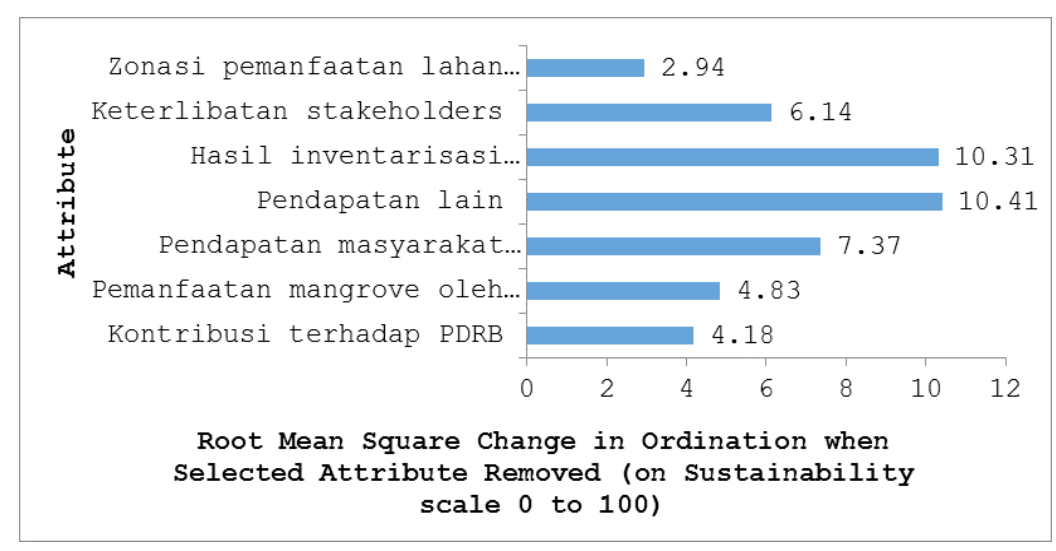

Sumber (Source): Data Primer, diolah (Primary data, processed)

Gambar 5. Hasil analisis leverage (sensitivitas) dimensi ekonomi

Figure 5. Result analysis of leverage (sensitivity) of economic dimension.

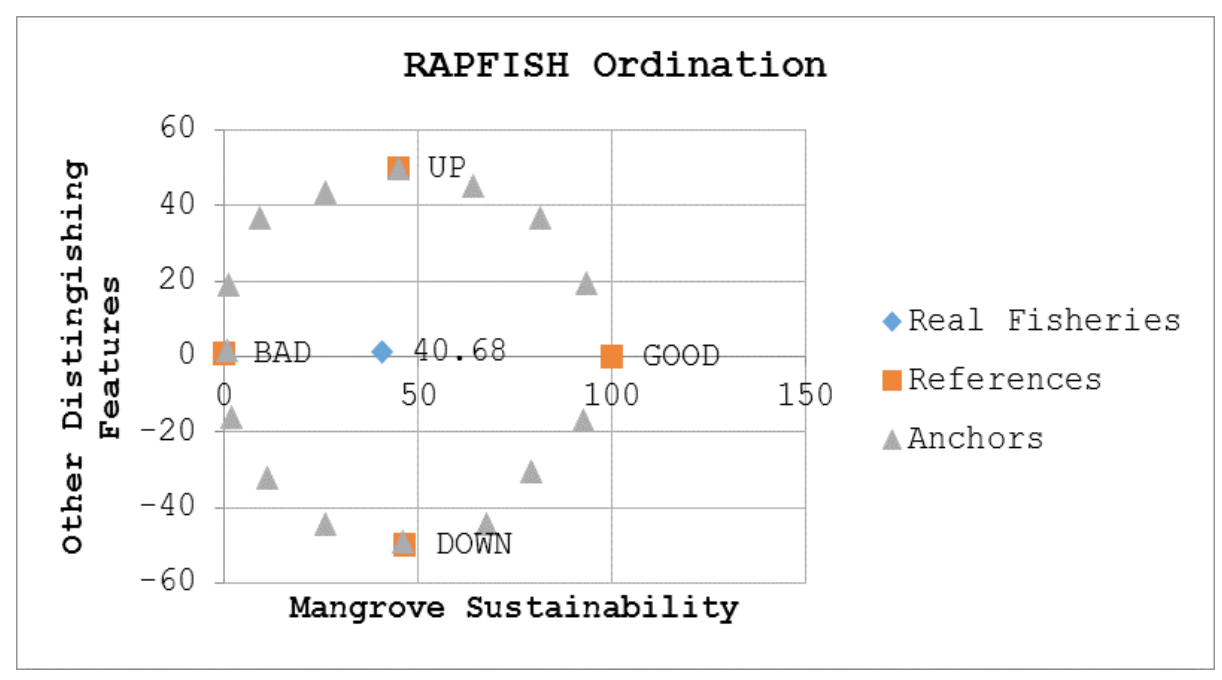

Sumber (Source): Data Primer, diolah (Primary data, processed)

Gambar 6. Indeks keberlanjutan dimensi sosial

Figure 6. Social dimension sustainability index.

Hasil analisis leverage dimensi ekonomi pada Gambar 5 menunjukkan bahwa terdapat tiga indikator yang sensitif terhadap nilai indeks keberlanjutan dari dimensi tersebut, yaitu (1) hasil inventarisasi pemanfaatan hutan mangrove, (2) pendapatan lain, dan (3) pendapatan masyarakat terhadap UMR.

Hasil analisis MDS menggunakan RAPFISH menunjukkan bahwa nilai indeks keberlanjutan pada dimensi sosial 40,68\% (kurang berkelanjutan).
Indikator yang dinilai pada dimensi ini ada sebanyak delapan indikator, yaitu (1) pengetahuan tentang mangrove, (2) tingkat pendidikan masyarakat, (3) akses masyarakat terhadap mangrove, (4) kerusakan ekosistem mangrove oleh masyarakat, (5) kesadaran masyarakat akan pentingnya mangrove, (6) kearifan lokal, (7) peran serta dalam pengelolaan mangrove, (8) konflik pemanfaatan mangrove. 
Hasil analisis leverage pada dimensi sosial menunjukkan tiga indikator yang sensitif terhadap nilai indeks keberlanjutan dari dimensi tersebut, yaitu (1) kerusakan ekosistem mangrove oleh masyarakat, (2) akses masyarakat lokal terhadap ekosistem mangrove, (3) kesadaran masyarakat terhadap pentingnya sumberdaya mangrove.

Hasil analisis MDS menggunakan RAPFISH menunjukkan bahwa nilai indeks keberlanjutan pada dimensi kelembagaan 63,68\% (cukup berkelanjutan).

Indikator yang dinilai pada dimensi ini ada sebanyak delapan indikator, yaitu (1) kebijakan dan perencanaan pengelolaan mangrove, (2) ketersediaan aturan dan peran lembaga non-formal, (3) keterlibatan lembaga masyarakat, (4) koordinasi antar lembaga atau stakeholders, (5) ketersediaan penyuluh atau petugas lapangan, (6) kepatuhan terhadap aturan pengelolaan, (7) pemberian sanksi bagi pelanggar, (8) pemantauan dan pengawasan.

Hasil analisis leverage pada dimensi kelembagaan, dimana terdapat empat indikator yang sensitif terhadap nilai indeks keberlanjutan dari dimensi tersebut yaitu (1) kepatuhan terhadap aturan pengelolaan, (2) koordinasi antar lembaga/stakeholders, (3)

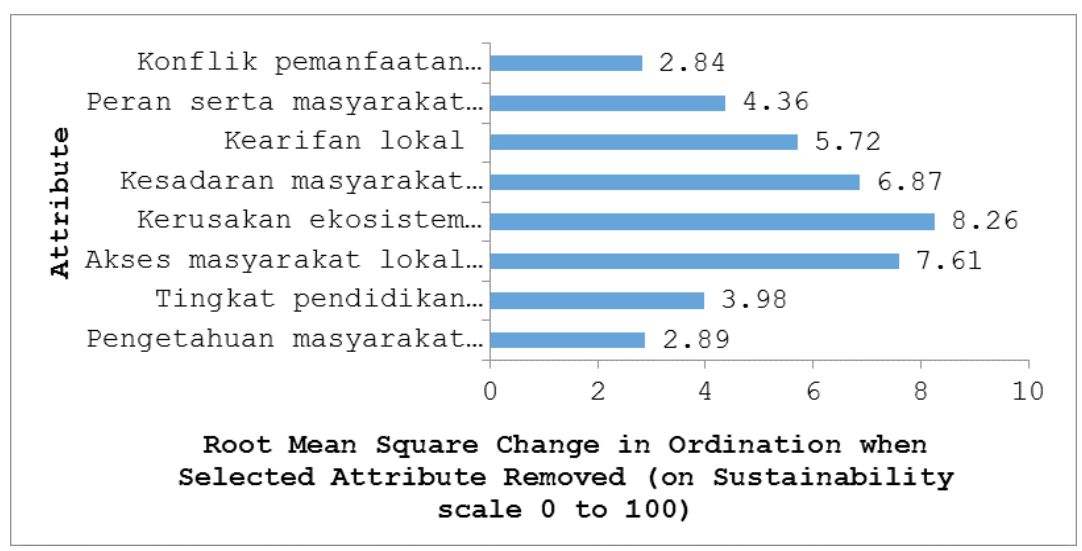

Sumber (Source): Data Primer, diolah (Primary data, processed)

Gambar 7. Hasil analisis leverage (sensitivitas) dimensi sosial Figure 7. Result analysis of leverage (sensitivity) of social dimension.

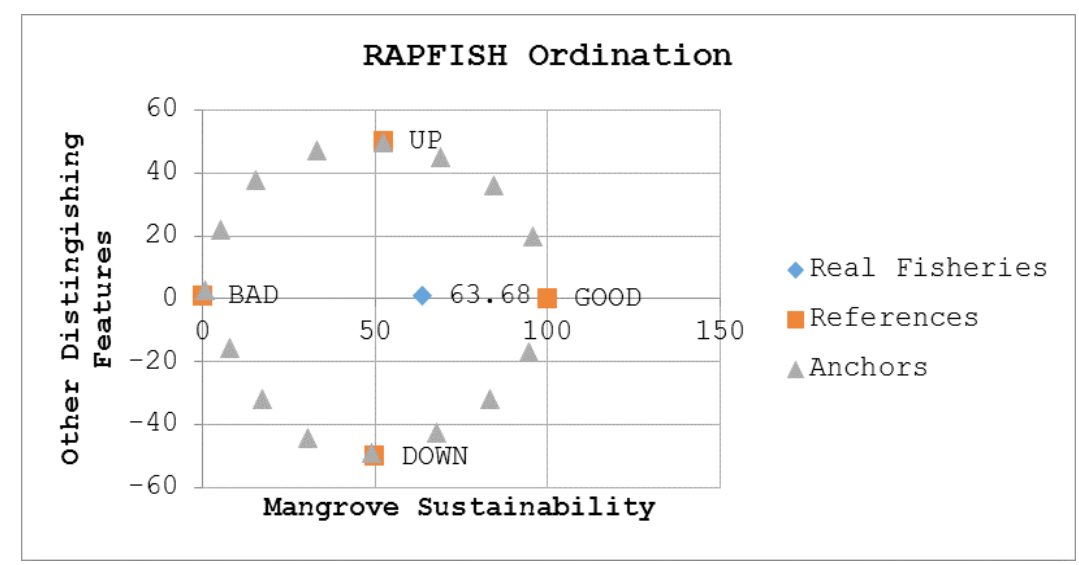

Sumber (Source): Data Primer, diolah (Primary data, processed)

Gambar 8. Indeks keberlanjutan dimensi kelembagaan Figure 8. Institutional dimension sustainability index. 


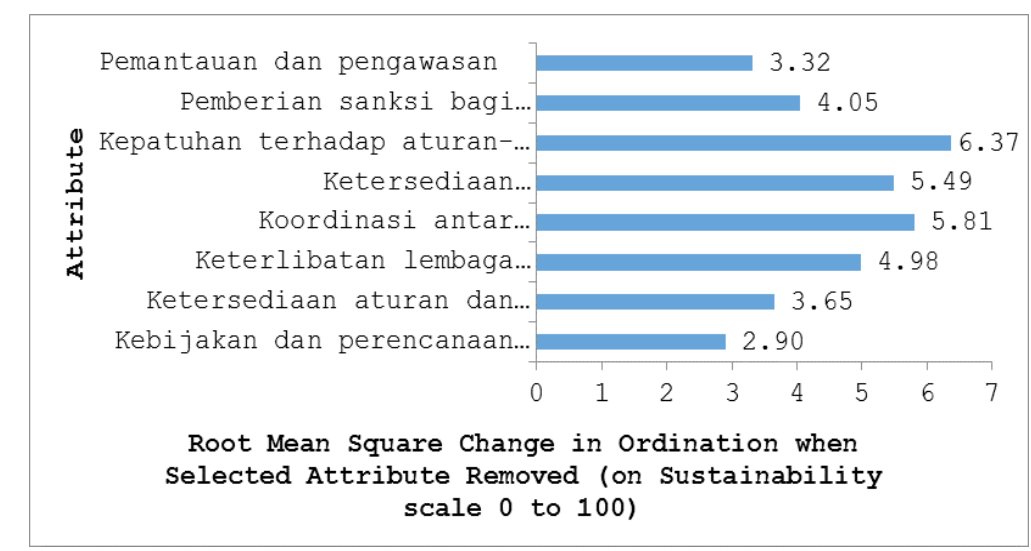

Sumber (Source): Data Primer, diolah (Primary data, processed)

Gambar 9. Hasil analisis leverage (sensitivitas) dimensi kelembagaan

Figure 9. Result analysis of leverage (sensitivity) of institutional dimension.

Tabel 2. Hasil uji validasi parameter statistik dimensi keberlanjutan

Table 2. Results of statistical parameter validation test on the sustainability dimension.

\begin{tabular}{lccccc}
\hline \multirow{2}{*}{ Parameter (Parameter) } & \multicolumn{6}{c}{ Dimensi Keberlanjutan (Sustainability Dimensions) } \\
\cline { 2 - 6 } & A & B & C & D & E \\
\hline Stress & 0.16 & 0.17 & 0.16 & 0.19 & 0.13 \\
$\begin{array}{l}\text { Squared Correlation } \\
\text { (RSQ) }\end{array}$ & 0.91 & 0.90 & 0.89 & 0.87 & 0.94 \\
Iterasi & 3.00 & 3.00 & 3.00 & 3.00 & 2.00 \\
\hline
\end{tabular}

Sumber (Source): Data Primer, diolah (Primary data,processed)

Tabel 3. Perbedaan nilai indeks keberlanjutan analisis monte carlo dengan analisis RAPFISH

Table 3. Difference between the value of sustainability index of Monte Carlo analysis and RAPFISH analysis

\begin{tabular}{lccccc}
\hline \multirow{2}{*}{ Hasil (Results) (\%) } & \multicolumn{5}{c}{ Dimensi Keberlanjutan } \\
\cline { 2 - 6 } & A & B & C & D & Dainability dimensions) \\
\hline RAPFISH & 21.72 & 49.15 & 40.68 & 63.68 & 45.49 \\
Monte Carlo & 23.83 & 49.12 & 41.38 & 62.54 & 45.74 \\
Perbedaan & 2.11 & 0.03 & 0.70 & 1.14 & 0.25 \\
\hline
\end{tabular}

Sumber (Source): Data Primer, diolah (Primary data, processed)

ketersediaan penyuluh atau petugas lapangan, dan (4) keterlibatan lembaga masyarakat.

Nilai validasi parameter statistik yang dihasilkan dalam analisis RAPFISH berbasis MDS berguna sebagai standar untuk menentukan kelayakan serta tingkat akurasi terhadap baik buruknya hasil analisis pada setiap dimensi dan dimensi gabungan yang telah dilakukan pada areal wilayah studi.
Parameter statistik yang dimaksud disajikan pada Tabel 2.

Hasil analisis Monte Carlo yang didapat dalam penelitian menunjukkan nilai yang tidak banyak mengubah nilai indeks multidimensi dan masing-masing dimensi. Perbedaan nilai indeks keberlanjutan analisis RAPFISH dan Monte Carlo pada setiap dimensi pengukuran disajikan pada Tabel 3 . 


\section{B. Pembahasan}

Dimensi pengelolaan yang digunakan dalam penelitian ini meliputi dimensi ekologi, ekonomi, sosial, dan kelembagaan dengan total indikator penilaian sebanyak 30 atribut. Terdapat sebanyak 16 indikator dari empat dimensi kunci, yaitu dimensi ekologi, sosial, ekonomi, dan kelembagaan. Setiap dimensi pengelolaan memiliki indikator (atribut) yang berbeda dalam mencerminkan status keberlanjutan dari dimensi tersebut dan keterwakilannya ditentukan oleh kisaran nilai yang dihasilkan dalam skala ordinasi dengan kategori berikut: berkelanjutan (nilai indeks sebesar 75-100\%); cukup berkelanjutan (nilai indeks sebesar 50-75\%); kurang berkelanjutan (nilai indeks sebesar 25-50\%); tidak berkelanjutan (nilai indeks sebesar $0-25 \%$ ).

Hasil analisis MDS dengan menggunakan RAPFISH menunjukkan nilai indeks keberlanjutan dimensi ekologi sebesar $21,72 \%$ (tidak berkelanjutan). Hasil analisis leverage pada dimensi ekologi menunjukkan empat indikator yang sensitif terhadap nilai indeks keberlanjutan dari dimensi tersebut, yaitu: (1) rehabilitasi ekosistem mangrove, (2) keanekaragaman mangrove, (3) keanekaragaman fauna mangrove, dan (4) tutupan mangrove.
Program rehabilitasi ekosistem mangrove di lokasi penelitian masih dirasa belum sepenuhnya berjalan dengan baik dikarenakan parapemangkukepentinganyangbersangkutan dengan ekosistem mangrove tersebut dinilai belum berkolaborasi dalam upaya pengelolaan wilayah tersebut, dalam kondisi ini maka mengakibatkan indikator tersebut berpengaruh dalam analisis keberlanjutan dari dimensi ekologi. Faktor utama yang menyebabkan rendahnya keanekaragaman mangrove di kecamatan tersebut adalah tingginya dominansi dari beberapa famili mangrove tertentu, yaitu $R$. mucronata, $A$. alba, dan $S$. caseolaris yang ditemukan pada lokasi penelitian. Faktor lain tidak lepas dari aktivitas antropogenik manusia dalam memanfaatkan kawasan, seperti konversi lahan untuk tambak dan pemukiman serta peruntukan lainnya. Aktivitas pemanfaatan kawasan tersebut telah berdampak pada hilangnya tutupan ekosistem mangrove pada tahun 1990 hingga sekitar tahun 2010. Schaduw et al., (2011) menyatakan bahwa penurunan luas hutan mangrove merupakan ancaman serius terhadap keberadaan sumber daya dengan kondisi penduduk yang sangat bergantung pada ekosistem mangrove untuk memenuhi kebutuhan secara ekonomis.

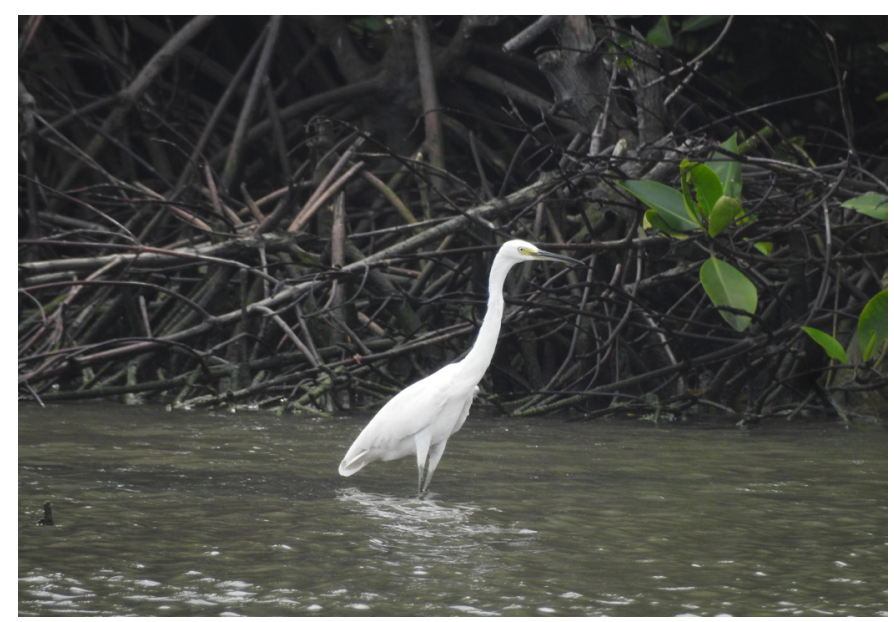

Sumber (Source): Data Primer (Primary data)

Gambar 10. Satwa yang dijumpai pada ekosistem mangrove di Kecamatan Tarumajaya Figure 10. The fauna found in the mangrove ecosystem in Tarumajaya District. 


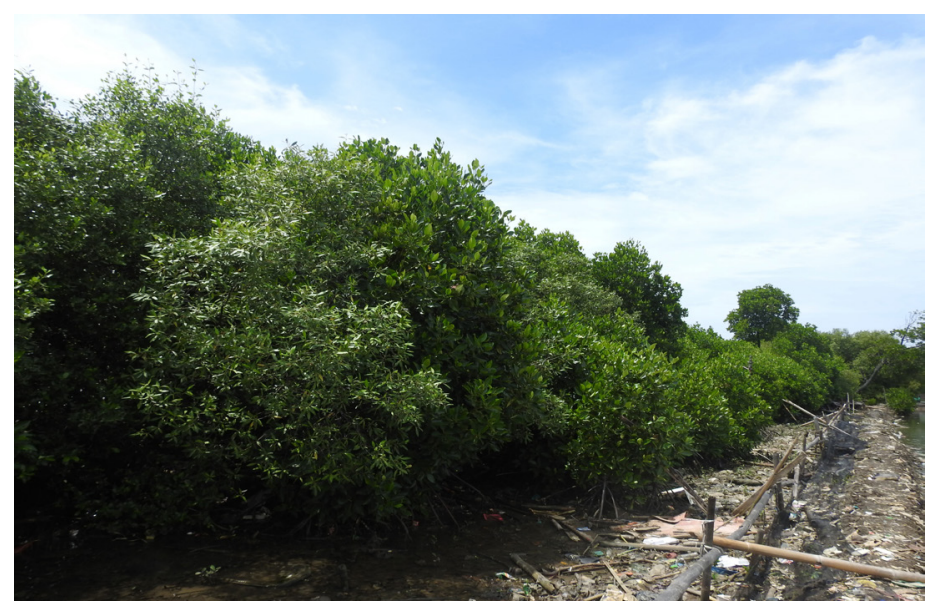

Sumber (Source): Data Primer (Primary data)

Gambar 11.Stasiun penelitian kesatu status keberlanjutan pengelolaan ekosistem mangrove di Kecamatan Tarumajaya

Figure 11. First research station on the status of sustainability mangrove ecosystem management in Tarumajaya District.

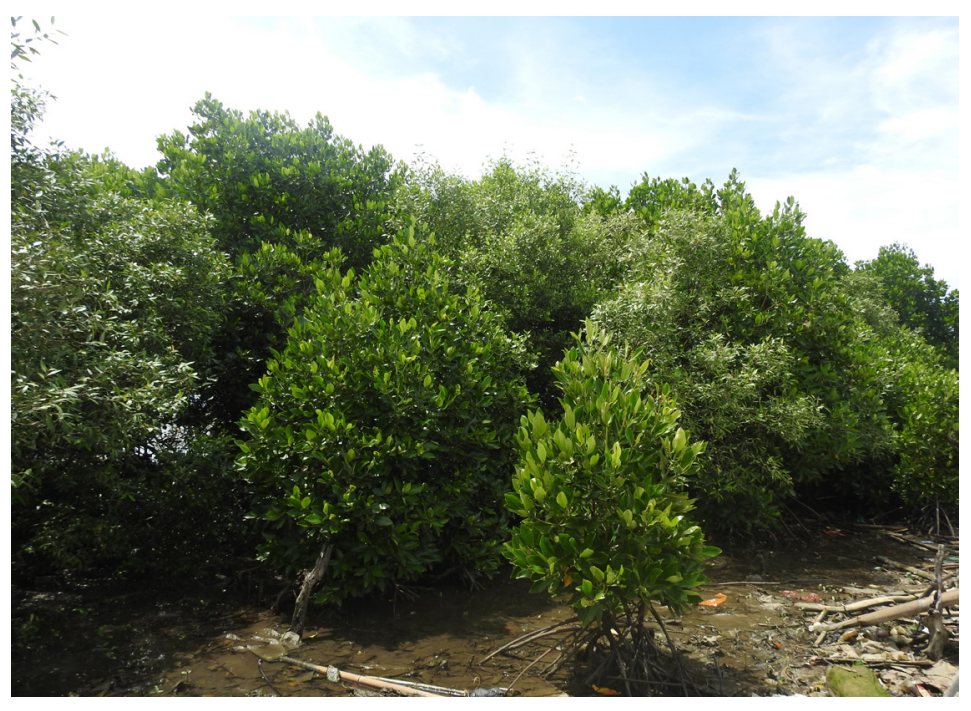

Sumber (Source): Data Primer (Primary data)

Gambar 12. Stasiun penelitian kedua status keberlanjutan pengelolaan ekosistem mangrove di Kecamatan Tarumajaya

Figure 12. Second research station on the status of sustainability mangrove ecosystem management in Tarumajaya District.

Rehabilitasi ekokosistem mangrove tambak maupun pada lahan terbuka yang yang telah dirintis oleh anggota swadaya mengalamidegradasi. Rehabilitasi merupakan masyarakat terutama pihak pengelola upaya dalam memulihkan dan menciptakan kawasan wisata di Kecamatan Tarumajaya habitat menjadi yang lebih stabil (Rusdianti mengindikasikan munculnya kesadaran \& Sunito, 2012). Ngongolo et al., (2015) pelestarian lingkungan. Hal ini terwujud menambahkan bahwa pemulihan mangrove melalui penanaman mangrove pada areal merupakan solusi parsial yang memerlukan yang rusak secara fisik, seperti lahan bekas upaya perlindungan secara menyeluruh dan 
konservasi agar ekosistem yang tersisa tidak mengalami kerusakan lebih parah. Oleh sebab itu, atribut ini wajib untuk terus ditingkatkan agar keberlanjutan mangrove secara ekologis dapat terjaga secara lestari.

Berdasarkan hasil analisis MDS menggunakan nilai indeks keberlanjutan pada dimensi ekonomi adalah 49,15\% (kurang berkelanjutan). Hasil analisis leverage dimensi ekonomi menunjukkan bahwa terdapat tiga indikator yang sensitif terhadap nilai indeks keberlanjutan dari dimensi tersebut, yaitu (1) hasil inventarisasi pemanfaatan hutan mangrove, (2) pendapatan lain, dan (3) pendapatan masyarakat terhadap UMR.

Hasil inventarisasi pemanfaatan ekosistem mangrove di Kecamatan Tarumajaya masih sangat kurang. Inventarisasi sejatinya adalah upaya yang dilakukan dalam menyediakan data faktual terkait jenis pemanfaatan, potensi mangrove yang dapat dikembangkan, kontribusi mangrove dalam mendukung produksi sektor perikanan dan informasi tentang kerusakan mangrove. Hal tersebut bertujuan agar memudahkan pengambilan langkah strategis, efisien dan efektif dalam pengelolaan mangrove di kecamatan tersebut. Perbaikan indikator perlu dilakukan dengan menyediakan baseline data dalam pengelolaan mangrove sebagaimana yang diamanatkan UU No. 27 Tahun 2007. Pemerintah daerah wajib memutakhirkan data sumber daya pesisir dan pulau-pulau kecil secara periodik yang didokumentasikan sebagai dokumen publik secara resmi untuk dimanfaatkan oleh masyarakat atau pemangku kepentingan dengan mempertimbangkan seluruh aspek keberlanjutan dalam pengelolaannya.

Keberadaan mangrove di Kecamatan Tarumajaya belum memberikan manfaat ekonomis secara optimal bagi masyarakat meskipun pemanfaatan mangrove yang dilakukan secara langsung tergolong tinggi. Total nilai manfaat yang diperoleh dalam analisis pemanfaatan langsung ekosistem mangrove di Kecamatan Tarumajaya merupakan nilai justifikasi atau estimasi nilai dari barang dan jasa yang diberikan oleh sumber daya tersebut berdasarkan pendekatan harga pasar yang berlaku saat itu sehingga tidak dapat dijadikan patokan bahwa nilai manfaat tersebut setara dengan pendapatan yang diperoleh oleh masyarakat. Kondisi ini memicu masyarakat untuk mencari jenis usaha sampingan lain.

Jenis usaha sampingan yang dilakukan masyarakat seperti bertani rumput laut, memperbaiki perahu, dan berdagang dianggap belum cukup memadai untuk menjamin tingkat kebutuhan rumah tangga mereka meskipun dapat menghasilkan pendapatan yang tergolong tinggi jika dibandingkan dengan upah minimum kota/kabupaten Bekasi. Pemanfaatan dan pengolahan produk turunan dari mangrove belum banyak diketahui oleh masyarakat, dan pemerintah setempat belum menyediakan wadah untuk memasarkan produk tersebut sehingga animo masyarakat untuk mengembangkan produk turunan mangrove seperti makanan dodol, sirup, dan produk lainnya masih rendah. Usaha dagang sebagian besar dilakukan oleh kepala rumah tangga sehingga dapat disimpulkan bahwa ibu rumah tangga belum berperan signifikan dalam usaha membantu memenuhi kebutuhan hidup. Kondisi tersebut didukung oleh data BPS Kab. Bekasi (2018) bahwa proporsi peran serta perempuan dalam aktivitas memenuhi kebutuhan hidup mendekati angka hampir hanya setengahnya saja dari peran serta kaum laki-laki. Selain itu, profesi dalam usaha perikanan pun dijalankan oleh kaum laki-laki dengan proporsi dua kali lipat jika dibandingkan dengan kaum perempuan. Faktor lain yang mempengaruhi belum sejahteranya masyarakat pesisir setempat dikarenakan pengelolaan keuangan rumah tangga yang belum terkelola dengan baik disebabkan ditunjukkan dengan kemampuan menyimpan pendapatan yang buruk dan tidak terkendali.

Hasil analisis MDS menggunakan RAPFISH menunjukkan bahwa nilai indeks keberlanjutan pada dimensi sosial 40,68\% 
(kurang berkelanjutan). Hasil analisis leverage pada dimensi sosial menunjukkan tiga indikator yang sensitif terhadap nilai indeks keberlanjutan dari dimensi tersebut, yaitu (1) kerusakan ekosistem mangrove oleh masyarakat, (2) akses masyarakat lokal terhadap ekosistem mangrove, (3) kesadaran masyarakat terhadap pentingnya sumberdaya mangrove.

Akses masyarakat Kecamatan Tarumajaya terhadap ekosistem mangrove cukup tinggi yang ditandai dengan tidak adanya aturan pembatasan akses terhadap sumber daya tersebut. Pengelolaan kawasan mangrove pada dasarnya tidak boleh mengesampingkan masyarakat setempat, terbukanya akses bagi masyarakat lokal memudahkan distribusi manfaat sumber daya tersebut baik secara langsung maupun tidak langsung sehingga dapat meningkatkan kesejahteraan masyarakat. Akses yang terbuka pada sisi lain dalam sumber daya mangrove tanpa adanya pengaturan yang jelas berdampak pada kerusakan ekosistem mangrove yang dilakukan oleh masyarakat. Kustanti (2013) menyatakan bahwa sumber daya hutan mempunyai karakteristik sebagai sumber daya milik bersama (Common Pool Resources) memiliki kecenderungan rusak dari waktu ke waktu yang disebabkan belum terdefenisinya sumber daya dan pengelolaanya dengan baik. Namun, seiring dengan berjalannya waktu masyakarat mulai menyadari akan pentingnya menjaga ekosistem mangrove sehingga akses pemanfaatan mereka semakin lama semakin dibatasi.

Walaupun dalam tingkat pemahaman atau persepsi masyarakat terhadap ekosistem mangrove tergolong tinggi namun pada praktiknya, kesadaran masyarakat akan arti penting keberadaan mangrove di Kecamatan Tarumajaya masih perlu dibenahi. Hal ini berkaitan dengan rendahnyatingkatpendidikan masyarakat di kecamatan tersebut. Kondisi ini berpengaruh terhadap perilaku, pemahaman, partisipasi serta kepedulian masyarakat dalam pengelolaan dan pemanfaatan sumber daya mangrove sebagai salah satu penunjang kebutuhan hidup. Pattimahu (2010) menyatakan rendahnya tingkat kesadaran masyarakat untuk melestarikan mangrove disebabkan oleh kurangnya pemahaman

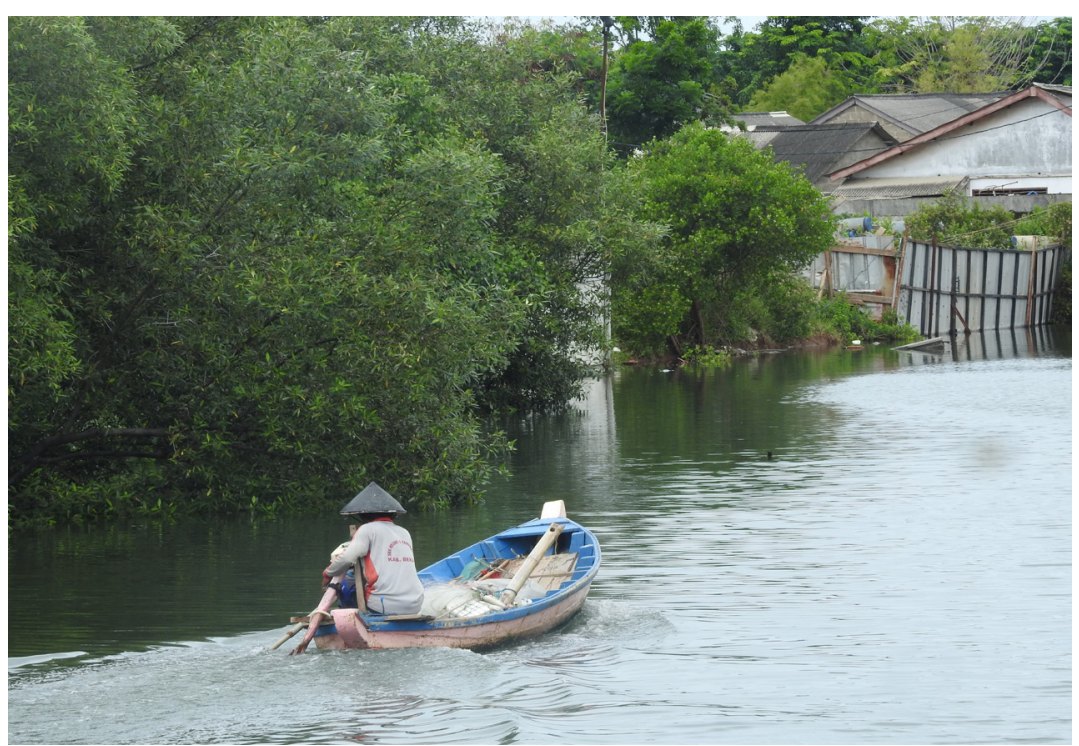

Sumber (Source): Data Primer (Primary data)

Gambar 13.Nelayan lokal yang dijumpai pada ekosistem mangrove di Kecamatan Tarumajaya Figure 13. The local fishing community found in a mangrove ecosystem in Tarumajaya District. 
terhadap dampak kerusakan hutan mangrove yang akan dirasakan oleh masyarakat.

Masalah sosial yang multikompleks di kecamatan ini adalah meningkatnya jumlah penduduk disertai dengan tingkat kebutuhannya. Berdasarkan data BPS Kab. Bekasi (2018) diketahui bahwa laju pertumbuhan penduduk (LPP) Kecamatan Tarumajaya selama 4 tahun terakhir (20132018) mencapai angka rata-rata $4,8 \%$ setiap tahunnya dengan wilayah desa yang memiliki jumlah penduduk terbanyak adalah Desa Setia Asih sebesar 46.106 jiwa. Angka tersebut diperkirakan akan terus mengalami peningkatan di waktu yang akan datang. Tidak ditemukannya kearifan lokal dalam upaya pengelolaan ekosistem mangrove di Kecamatan Tarumajaya berdampak terhadap kelestarian pengelolaan ekosistem. Peran penting yang dimainkan kearifan lokal dianggap mampu untuk menekan kerusakan ekosistem.

Prinsip peran serta masyarakat pada umumnya bukan hanya sebagai slogan semata namun harus dilaksanakan secara tegas mencakup berbagai kepentingan masyarakat yaitu; kesetaraan dan kemitraan, transparansi, distribusi kewenangan yang seimbang, kesetaraan tanggung jawab, serta pemberdayaan dan kerjasama (Anwar, 2011). Kurangnya peran serta masyarakat di Kecamatan Tarumajaya dalam pengelolaan ekosistem mangrove tergantung dari ada tidaknya program pemerintah untuk memberdayakan masyarakat. Peran serta masyarakat secara langsung merupakan bentuk interaksi sosial yang sangat penting dalam menentukan keberhasilan pengelolaan mangrove yang berkelanjutan. Masyarakat dapat dijadikan mitra dalam pengelolaan mangrove bersama pemerintah melalui sistem pengelolaan hutan bersama sehingga seluruh kepentingaan dapat diakomodir. Kustanti (2013), pengelolaan sumber daya milik bersama memerlukan pilihan pemanfaatan bersama, kebijakan bersama, dan aksi bersama dalam kelestarian pengelolaannya.
Hasil analisis MDS menggunakan RAPFISH menunjukkan bahwa nilai indeks keberlanjutan pada dimensi kelembagaan 63,68\% (cukup berkelanjutan). Hasil analisis leverage pada dimensi kelembagaan, dimana terdapat empat indikator yang sensitif terhadap nilai indeks keberlanjutan dari dimensi tersebut yaitu: (1) kepatuhan terhadap aturan pengelolaan, (2) koordinasi antar lembaga/ stakeholders, (3) ketersediaan penyuluh atau petugas lapangan, dan (4) keterlibatan lembaga masyarakat.

Pengelolaan ekosistem mangrove berkelanjutan merupakan usaha yang sangat kompleks untuk dilaksanakan karena kegiatan tersebut membutuhkan sifat akomodatif dan adanya mekanisme kerja samayang kolaboratif antar berbagai pihak yang bersangkutan untuk bermusyawarah bersama secara bottom-up mewakili lembaga atau instansi masingmasing. Hal ini bertujuan agar setiap rencana kegiatan pengelolaan mangrove berkelanjutan dapat terlaksana dengan baik dan tidak terjadi konflik kepentingan antar pihak. Oleh sebab itu, koordinasi antar lembaga dan stakeholders dalam pengelolaan ekosistem mangrove di pesisir Kecamatan Tarumajaya harus ditingkatkan dengan melibatkan peran serta masyarakat maupun lembaga masyarakat serta pengelola kawasan diantaranya Dinas Perikanan dan Kelautan, Dinas Pariwisata, Perum Perhutani, Pemerintah Kabupaten Bekasi, Pemerintah Desa, POKDARWIS (Kelompok Sadar Wisata), POKMASWAS (Kelompok Masyarakat Pengawas), BUMDES (Badan Usaha Milik Desa), tokoh masyarakat, serta masyarakat sekitar pesisir Kecamatan Tarumajaya.

Hubungan yang terjadi antara stakeholder yang terlibat dalam pengelolaan ekosistem mangrove Kecamatan Tarumajaya, yaitu potensi konflik dan kerja sama. Potensi konflik yang dikhawatirkan, yaitu adanya saling klaim kawasan. Kegiatan pengelolaan dan pengembangan ekosistem mangrove sepenuhnya diserahkan kepada masyarakat sebagai aktor utama pengelolaan. Konflik 
dikhawatirkan akan terjadi antar masyarakat yang terlibat dengan yang tidak terlibat dalam pengembangan ekosistem mangrove khususnya ekowisata, yaitu konflik kecemburuan sosial. Perbaikan kinerja dari stakeholder yang terkait dengan pengembangan ekosistem mangrove diperlukan perubahan dan perbaikan kondisi terkait peran dan kapasitas sedangkan dari faktor aturan main adalah terkait dengan pembagian kewenangan (Latupapua, 2015).

Dinas Pariwisata dan Dinas Kelautan dan Perikanan merupakan lembaga yang yang berperan aktif dalam membantu promosi dan memfasilitasi peningkatan saran dan prasarana wisata pada lokasi studi. Kemudian dukungan dan peranan dinas terkait lainnya dibutuhkan untuk pengembangan ekosistem mangrove di Kecamatan Tarumajaya.

Status keberlanjutan pengelolaan ekosistem mangrove di Kecamatan Tarumajaya tergolong kurang berkelanjutan yang ditandai dengan nilai indeks hasil analisis pada dimensi gabungan (multidimensi) sebesar 45,79\%. Perbandingan hasil analisis keberlanjutan pengelolaan ekosistem mangrove pada dimensi-dimensi tersebut kemudian divisualisasikan dalam bentuk diagram layang (kite diagram) seperti yang disajikan pada Gambar 14.
Artinya, pengelolaan ekosistem mangrove di Kecamatan Tarumajaya, Kabupaten Bekasi membutuhkan dukungan manajemen pengelolaan yang memprioritaskan kinerja atau output yang baik dan seimbang pada masing-masing indikator kunci yang sensitif untuk mencapai peningkatan status keberlanjutan pengelolaan ekosistem mangrove.

Validasi hasil analisis RAPFISH menunjukkan bahwa nilai koefisien determinasi RSQ $\left(\mathrm{R}^{2}\right)$ yang diperoleh berkisar antara $0,91-0,94 \%$ yang menunjukkan bahwa keseluruhan indikator dimensi yang dianalisis dalam keberlanjutan pengelolaan ekosistem mangrove memiliki peran yang cukup besar dalam menjelaskan keragaman dari nilai indeks dimensi. Nilai stress memiliki nilai kisaran antara $13-16 \%$ atau lebih rendah dari 0,25 (25\%) menunjukkan ketepatan konfigurasi titik (goodness of fit) model yang dibangun untuk status keberlanjutan indikator dimensi mempresentasikan model yang baik. Terdapat bermacam cara validasi, mulai yang bersifat deskriptif, misalnya melalui perbandingan secara grafis atau pengujian secara kuantitatif, yang dilakukan melalui uji statistik. Hal ini didukung oleh pendapat (Fauzi \& Anna, 2005). bahwa hasil analisis cukup memadai apabila nilai stress lebih

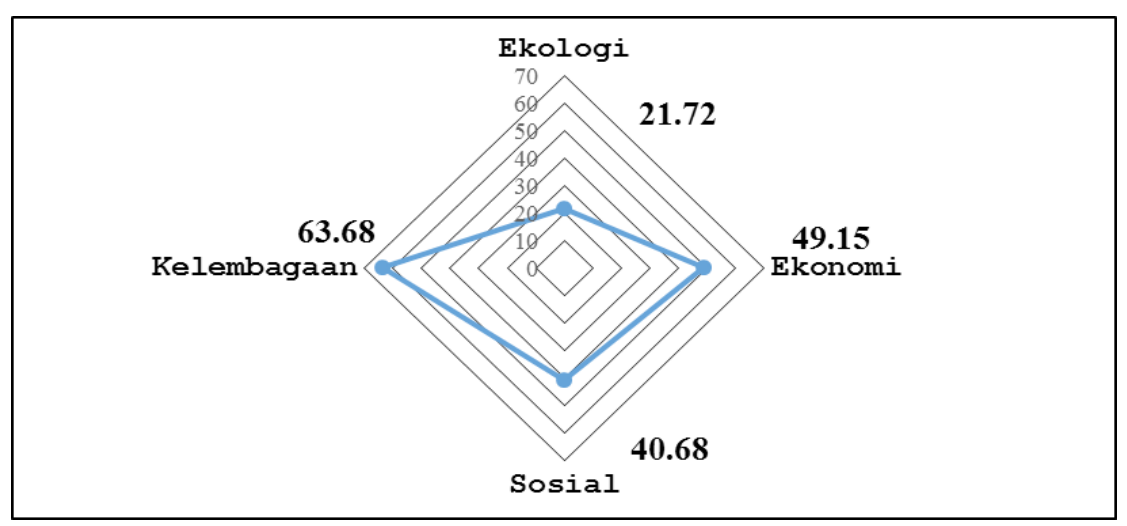

Sumber (Source): Data Primer (Primary data)

Gambar 14.Diagram layang (kite diagram) indeks keberlanjutan pengelolaan ekosistem mangrove di Kecamatan Tarumajaya

Figure 14. Kite diagram of the sustainability index mangrove ecosystem management in Tarumajaya District. 
kecil dari nilai 0,25 (25\%) dan nilai koefisien determinasi $\left(\mathrm{R}^{2}\right)$ mendekati nilai 1,00 . Semakin kecil nilai stress yang diperoleh berarti semakin baik kualitas analisis yang dilakukan dan nilai koefisien determinasi $\left(\mathrm{R}^{2}\right)$ kualitas hasil analisis berarti semakin baik jika nilai koefisien determinasi semakin besar (mendekati angka 1).

Analisis Monte Carlo digunakan untuk menguji tingkat kepercayaan nilai indeks total dan setiap dimensi pengelolaan. Analisis ini membantu melihat pengaruh kesalahan pembuatan skor pada setiap indikator dalam setiap dimensi yang disebabkan oleh kesalahan prosedur atau pemahaman terhadap indikator, variasi pemberian skor karena perbedaan pendapat, stabilitas proses analisis MDS, kesalahan memasukkan data atau data hilang dan nilai stress yang terlalu tinggi. Dengan demikian, kecilnya perbedaan nilai hasil analisis Monte Carlo menjelaskan bahwa pengunaan metode RAPFISH berbasis MDS dalam menentukan status keberlanjutan pengelolaan ekosistem mangrove di Kecamatan Tarumajaya, Kabupaten Bekasi mempunyai tingkat kepercayaan yang tinggi.

\section{KESIMPULAN DAN SARAN}

\section{A. Kesimpulan}

$\begin{array}{clr}\begin{array}{c}\text { Status keberlanjutan } \\ \text { ekosistem }\end{array} & \begin{array}{r}\text { pengelolaan } \\ \text { mangrove di }\end{array}\end{array}$

Tarumajaya, Kabupaten Bekasi diperoleh nilai indeks multidimensi sebesar 45,79\% dengan status kurang berkelanjutan, nilai indeks dan status keberlanjutan pada setiap dimensi, yaitu dimensi ekologi 21,72\% (tidak berkelanjutan), dimensi ekonomi 49,15\% (kurang berkelanjutan), dimensi sosial 40,68\% (kurang berkelanjutan), dan dimensi kelembagaan 63,68 \% (cukup berkelanjutan). Masing-masing dimensi uji memiliki indikator sensitif yang digunakan untuk acuan melakukan perbaikan dan pengembangan kinerja agar status keberlanjutan kawasan dapat meningkat.
Indikator yang sensitif terhadap status keberlanjutan pengelolaan ekosistem mangrove di Kecamatan Tarumajaya pada dimensi ekologi dipengaruhi oleh program rehabilitasi ekosistem mangrove di lokasi penelitian masih dirasa belum sepenuhnya berjalan dengan baik. Indikator sensitif pada dimensi ekonomi dipengaruhi oleh hasil inventarisasi pemanfaatan ekosistem mangrove di Kecamatan Tarumajaya masih sangat kurang untuk dijadikan data dasar pedoman pengelolaan. Indikator sensitif pada dimensi sosial dipengaruhi oleh akses masyarakat pesisir Kecamatan Tarumajaya terhadap ekosistem mangrove cukup tinggi yang ditandai dengan tidak adanya aturan pembatasan penggunaan atau akses terhadap sumber daya tersebut. Indikator sensitif pada dimensi kelembagaan dipengaruhi oleh Hubungan yang terjadi antara stakeholder yang terlibat dalam pengelolaan ekosistem mangrove Kecamatan Tarumajaya, yaitu potensi konflik dan kerja sama. Potensi konflik yang dikhawatirkan, yaitu adanya saling klaim kepemilikan kawasan.

Pengelolaan ekosistem mangrove berkelanjutan harus mengevaluasi ke enam belas indikator sensitif tersebut secara seimbang agar terciptanya manajemen pengelolaan ekosistem mangrove di Kecamatan Tarumajaya, Kabupaten Bekasi.

\section{B. Saran}

Upaya pengelolaan ekosistem mangrove berkelanjutan diwajibkan melakukan perbaikan dan pengembangan kinerja dari 16 indikator yang tergolong sensitif untuk mendorong dan meningkatkan status keberlanjutan pengelolaan ekosistem mangrove di Kecamatan Tarumajaya, Kabupaten Bekasi. Adapun peningkatan dan pengembangan kinerja yang harus diterapkan meliputi konservasi kawasan dengan penataan zonasi kawasan pengelolaan, upaya perlindungan vegetasi dan satwa, pemanfaatan ekosistem mangrove yang berkontribusi 
bagi penciptaan lapangan pekerjaan dan meningkatkan pendapatan serta kesejahteraan masyarakat pesisir, menyediakan fasilitator sebagai pendamping bagi masyarakat untuk melakukan penyuluhan mengenai pentingnya menjaga ekosistem mangrove, melakukan pengawasan dan penegakan aturan pengelolaan serta penguatan koordinasi keseluruhan stakeholder yang berwenang dalam manajemen pengelolaan ekosistem mangrove secara keberlanjutan bersama masyarakat.

\section{UCAPAN TERIMA KASIH (ACKNOWLEDGEMENT)}

Penulis mengucapkan terima kasih sebesar-besarnya kepada Pihak Pengelola ekosistem mangrove Kecamatan Tarumajaya, Pemerintahan Tingkat Desa, Kecamatan, dan Kabupaten Bekasi karena atas upaya memfasilitasi peneliti selama melakukan penelitian dan penulisan artikel ini.

\section{DAFTAR PUSTAKA}

Anwar, R. (2011). Pengembangan dan Keberlanjutan Wisata Bahari di Wilayah Pesisir dan Pulau-Pulau Kecil Kota Makassar. (Tesis). Bogor (ID): Institut Pertanian Bogor.

Bae, S. H., Qiu, J., \& Fox, G. (2012). Adaptive interpolation of multidimensional scaling. Procedia Computer Science, 9, 393-402. https:// doi.org/10.1016/j.procs.2012.04.042.

[BPS] Badan Pusat Statistik Bekasi. (2018). Kabupaten Bekasi dalam Angka Bekasi 2018. Bekasi (ID): BPS Kabupaten Bekasi.

Cissé, A. A., Blanchard, F., \& Guyader, O. (2014). Sustainability of tropical small-scale fisheries: Integrated assessment in French Guiana. Marine Policy, 44, 397-405. https://doi.org/10.1016/j. marpol.2013.10.003.

Fauzi, A., \& Anna. (2005). Permodelan Sumber Daya Perikanan dan Kelautan. Jakarta (ID): Gramedia Pustaka Utama.

Giri, C., Long, J., Abbas, S., Murali, R. M., Qamer, F. M., Pengra, B., \& Thau, D. (2015). Distribution and dynamics of mangrove forests of South Asia. Journal of Environmental Management, 148, 101-111. https://doi.org/10.1016/j. jenvman.2014.01.020
[KEPMENLH] Kementerian Lingkungan Hidup dan Kehutanan. (2004). Keputusan Menteri Lingkungan Hidup No. 201 Tahun 2004 tentang Kriteria Baku dan Pedoman Penentuan Kerusakan Mangrove. Jakarta (ID): Kementerian Lingkungan Hidup dan Kehutanan.

Kuenzer, C., Bluemel, A., Gebhardt, S., Quoc, T. V., \& Dech, S. (2011). Remote sensing of mangrove ecosystems: A review. In Remote Sensing, 3(5). https://doi.org/10.3390/rs3050878.

Kusmana, C. (2014). Peranan Ekosistem Mangrove bagi Pertahanan dan Keamanan NKRI. Bogor (ID): Institut Pertanian Bogor.

Kustanti, A. (2013). Evolusi hak kepemilikan dan penataan peran para pihak pada pengelolaan ekosistem hutan mangrove dengan kemunculan tanah timbul (kasus pada tanah timbul hutan mangrove di Kabupaten Lampung Timur Provinsi Lampung. (Disertasi). Bogor (ID): Institut Pertanian Bogor.

Latupapua, Y. (2015). Implementasi Peran Stake Holder dalam Pengembangan Ekowisata di Taman Nasional Manusela (TNM) di Kabupaten Maluku Tengah. Jurnal Agroforestri, X(1), 21-30.

Masood, H., Afsar, S., Zamir, U. Bin, \& Kazmi, J. H. (2015). Application of comparative remote sensing techniques for monitoring mangroves in Indus Delta, Sindh, Pakistan. Biological Forum An International Journal, 7(1), 783-792.

Mushimin. (2018). Strategi Pengelolaan Ekosistem Mangrove Berkelanjutan di Wilayah Pesisir Desa Akuni, Kecamatan Tinanggea, Kabupaten Konawe Selatan. (Tesis). Bogor (ID): Institut Pertanian Bogor.

Ngongolo, K., Mtoka, S., \& Mahulu, A. (2015). Challenges and Opportunities for Restoring the Threatened Mangroves. Journal of Scientific Research and Reports, 5(5), 352-360. https://doi. org/10.9734/jsrr/2015/8922.

Patang. (2012). Analisis strategi pengelolaan hutan mangrove (Kasus di Desa Tongke-Tongke Kabupaten Sinjai). Jurnal Agrisistem, 8(2).

Pattimahu, D. V. (2010). Kebijakan Pengelolaan hutan mangrove berkelanjutan di Kabupaten Seram Bagian Barat Maluku. (Disertasi). Bogor (ID): Institut Pertanian Bogor.

Pitcher, T. J., \& Preikshot, D. (2001). RAPFISH: A rapid appraisal technique to evaluate the sustainability status of fisheries. Fisheries Research, 49(3), 255-270. https://doi.org/10.1016/S01657836(00)00205-8.

Pramudji. (2011). Hutan mangrove di Indonesia: Peranan permasalahan dan pengelolaannya. Oseana, 25(1), 13-20.

Rusdianti, K., \& Sunito, S. (2012). Konversi lahan hutan mangrove serta upaya penduduk lokal 
dalam merehabilitasi ekosistem mangrove. Sodality: Jurnal Sosiologi Pedesaan, 6(1), 1-17. https://doi.org/10.22500/sodality.v6i1.5815.

Santoso, N. (2012). Arahan kebijakan dan strategi pengelolaan kawasan mangrove berkelanjutan di Muara Angke Daerah Khusus Ibukota Jakarta. (Disertasi). Bogor (ID): Institut Pertanian Bogor.

Sasidhar, K., Tirupathi, C., HemaKrishna, R., \& Vishnuvardhan, Z. (2013). Salinity studies of Bay of Bengal and identification of various salttolerant species of mangroves. International Journal Engineering and Science, 3(10), 555562.
Schaduw, joshian N., Fredinan, Y., Bengen, diertrieh G., \& Setyobudiandi, I. (2011). Pengelolaan ekosistem mangrove pulau-pulau kecil Taman Nasional Bunaken berbasis kerentanan. Jurnal Agribisnis, 12(3), 173-181.

Theresia, Boer, M., \& Pratiwi, N.T. (2015). Status keberlanjutan pengelolaan ekosistem mangrove di Taman Nasional Sembilang Kabupaten Banyuasin Provinsi Sumatera Selatan. Jurnal Ilmu dan Teknologi Kelautan Tropis, 7(2), 703714. 
Lampiran 1. Indikator dan kriteria skor keberlanjutan setiap dimensi pengelolaan ekosistem mangrove Kecamatan Tarumajaya, Kabupaten Bekasi

Appendix 1. Sustainability score of indicators and criteria for each dimension mangrove ecosystem management in Tarumajaya District, Bekasi Regency

\begin{tabular}{|c|c|c|}
\hline $\begin{array}{c}\text { Dimensi dan Indikator } \\
\text { (Dimensions and Indicators) }\end{array}$ & Keterangan (Description) & $\begin{array}{c}\text { Acuan Penentuan Kriteria } \\
\text { (Determination Reference Criteria) }\end{array}$ \\
\hline \multicolumn{3}{|l|}{ Ekologi (Ecology) } \\
\hline 1. Kerapatan mangrove & $\begin{array}{l}(0)=\text { jarang }(<1000 \text { pohon } / \text { ha }) \\
(1)=\text { sedang }(\geq 1000-1500 \text { pohon } / \mathrm{ha}) \\
(2)=\text { padat }(\geq 1500 \text { pohon } / \mathrm{ha})\end{array}$ & $\begin{array}{ll}\text { - } & \text { Observasi lapangan } \\
\text { - Kepmen LH No. } 201 \text { Tahun } \\
\\
2004\end{array}$ \\
\hline 2. Tutupan mangrove & $\begin{array}{l}(0)=\text { jarang }(\text { tutupan }<50 \%) \\
(1)=\text { sedang }(\text { tutupan } \geq 50-70 \%) \\
(2)=\text { sangat padat }(\text { tutupan } \geq 75 \%)\end{array}$ & $\begin{array}{ll}\text { - } & \text { Observasi lapangan } \\
\text { - Kepmen LH No. } 201 \text { Tahun } \\
2004\end{array}$ \\
\hline 3. Keanekaragaman mangrove & $\begin{array}{l}(0)=\operatorname{rendah}\left({ }^{\prime} \leq 1\right), \\
(1)=\text { sedang }\left(1<<^{\prime}<3\right), \\
(2)=\operatorname{tinggi}\left(H^{\prime}>3\right)\end{array}$ & $\begin{array}{ll}\text { - } & \text { Observasi lapangan } \\
\text { - } & \text { Indeks keanekaragaman } \\
& \text { Shannon-Wienner }\end{array}$ \\
\hline $\begin{array}{l}\text { 4. Keanekaragaman fauna } \\
\text { mangrove }\end{array}$ & $\begin{array}{l}(0)=\text { rendah }(\text { sedikit }) \\
(1)=\text { sedang }(\text { cukup beragam }), \\
(2)=\text { tinggi }(\text { sangat beragam })\end{array}$ & $\begin{array}{l}\text { - } \quad \text { Wawancara } \\
\text { - } \quad \text { Theresia et al. }(2015) \\
\text { *dimodifikasi }\end{array}$ \\
\hline $\begin{array}{l}\text { 5. Rehabilitasi ekosistem } \\
\text { mangrove }\end{array}$ & $\begin{array}{l}(0)=\text { rendah }(\leq 50 \%) \\
(1)=\text { sedang }(\geq 50-75 \%), \\
(2)=\operatorname{tinggi~}(>75 \%)\end{array}$ & $\begin{array}{ll}\text { - } & \text { Observasi lapangan } \\
\text { - } & \text { Pattimahu (2010) } \\
& * \text { dimodifikasi }\end{array}$ \\
\hline 6. Tekanan lahan mangrove & $\begin{aligned}(0)= & \text { tidak terjadi penurunan luas } \\
& \text { lahan mangrove; } \\
(1)= & \text { perubahan luas lahan mangrove } \\
& \text { secara alami; } \\
(2)= & \text { terjadi alih fungsi lahan } \\
& \text { mangrove tanpa memperhatikan } \\
& \text { fungsi lingkungan }\end{aligned}$ & $\begin{array}{ll}\text { - } & \text { Wawancara } \\
\text { - } & \text { Santoso (2012) }\end{array}$ \\
\hline 7. Perubahan garis pantai & $\begin{array}{l}(0)=\text { berkurang }(\text { abrasi) } \\
(1)=\text { tetap; } \\
(2)=\text { bertambah }(\text { akresi) }\end{array}$ & $\begin{array}{ll}\text { - } & \text { Wawancara } \\
\text { - } & \text { Santoso (2012) }\end{array}$ \\
\hline
\end{tabular}

\section{Sosial (Social)}

1. Pengetahuan masyarakat tentang mangrove

2. Tingkat pendidikan masyarakat

3. Akses masyarakat lokal terhadap ekosistem mangrove

4. Kerusakan ekosistem mangrove oleh masyarakat

5. Kesadaran masyarakat terhadap pentingnya sumber daya mangrove
(0) = rendah;

(1) = sedang;

(2) = tinggi

(1)= tidak sekolah dan tamat SD;

(2)= Lulus SD dan SMP;

(3)= Lulus SMA dan PT

(0) = tidak mempunyai akses sama sekali;

(1) = mempunyai akses yang rendah;

(2) = mempunyai akses yang tinggi

(1) = besar;

(2) = sedang;

(3) $=$ kecil

(0) = rendah $(<50 \%)$;

(1) = sedang $(50-75 \%)$;

(2) = tinggi $(75-100 \%)$
- Wawancara

- $\quad$ Pattimahu (2010)

- Wawancara

- Santoso (2012)

*dimodifikasi

- Wawancara

- $\quad$ Pattimahu (2010)

- Wawancara

- Pattimahu (2010)

- Observasi lapangan

- Pattimahu (2010)

*dimodifikasi 


\begin{tabular}{|c|c|c|}
\hline $\begin{array}{l}\text { Dimensi dan Indikator } \\
\text { (Dimensions and Indicators) }\end{array}$ & Keterangan (Description) & $\begin{array}{c}\text { Acuan Penentuan Kriteria } \\
\text { (Determination Reference Criteria) }\end{array}$ \\
\hline 6. Kearifan lokal & $\begin{array}{l}(0)=\text { tidak ada } \\
(1)=\text { ada, namun tidak efisien; } \\
(2)=\text { ada dan efisien }\end{array}$ & - Wawancara \\
\hline $\begin{array}{l}\text { 7. Peran serta masyarakat } \\
\text { dalam pengelolaan ekosistem } \\
\text { mangrove }\end{array}$ & $\begin{array}{l}(0)=\text { rendah }(<50 \%) ; \\
(1)=\text { sedang }(50-75 \%) ; \\
(2)=\text { tinggi }(75-100 \%)\end{array}$ & $\begin{array}{ll}\text { - } & \text { Wawancara } \\
\text { - } & \text { Pattimahu (2010) }\end{array}$ \\
\hline $\begin{array}{l}\text { 8. Konflik pemanfaatan sumber } \\
\text { daya mangrove }\end{array}$ & $\begin{array}{l}(0)=\text { banyak }(>5 \mathrm{kali} / \mathrm{tahun}) \\
(1)=\text { beberapa }(2-5 \mathrm{kali} / \mathrm{tahun}) \\
(2)=\operatorname{sedikit}(<2 \mathrm{kali} / \mathrm{tahun})\end{array}$ & $\begin{array}{ll}\text { - } & \text { Wawancara } \\
\text { - } & \text { Theresia et al. (2015) }\end{array}$ \\
\hline \multicolumn{3}{|l|}{ Ekonomi (Economy) } \\
\hline 1. Kontribusi terhadap PDRB & $\begin{array}{l}(0)=\text { rendah; } \\
(1)=\text { sedang; } \\
(2)=\text { tinggi }\end{array}$ & $\begin{array}{ll}\text { - } & \text { Wawancara } \\
\text { - } & \text { PDRB Kab. Bekasi } \\
\text { - } & \text { Pitcher \& Preikshot (2001) } \\
& \text { *dimodifikasi }\end{array}$ \\
\hline $\begin{array}{l}\text { 2. Pemanfaatan mangrove oleh } \\
\text { masyarakat }\end{array}$ & $\begin{aligned}(0)= & \text { rendah }(<25 \% \text { pemanfaatan } \\
& \text { langsung hasil hutan dan } \\
& \text { perikanan }) ; \\
(1)= & \text { sedang }(\geq 25-50 \% \text { pemanfaatan } \\
& \text { langsung hasil hutan dan } \\
& \text { perikanan }) ; \\
(2)= & \text { tinggi }(>50 \% \text { pemanfaatan } \\
& \text { langsung hasil hutan dan } \\
& \text { perikanan })\end{aligned}$ & $\begin{array}{ll}\text { - } & \text { Wawancara } \\
\text { - } & \text { Pattimahu (2010) } \\
& \text { *dimodifikasi }\end{array}$ \\
\hline $\begin{array}{l}\text { 3. Pendapatan masyarakat } \\
\text { terhadap UMR }\end{array}$ & $\begin{array}{l}(0)=(<\text { rata-rata UMR }) ; \\
(1)=(=\text { rata-rata UMR }) ; \\
(2)=(>\text { rata-rata UMR })\end{array}$ & $\begin{array}{ll}\text { - } & \text { Wawancara } \\
\text { - } & \text { Santoso (2012) } \\
\text { - } & \text { UMK Kab. Bekasi } 2021 \text { (Rp. } \\
& 4.791 .843)\end{array}$ \\
\hline 4. Pendapatan lain & $\begin{array}{l}\text { pemanfaatan dilakukan: } \\
(0)=\text { part time } \\
(1)=\text { musiman; } \\
(2)=\text { full time }\end{array}$ & $\begin{array}{ll}\text { - } & \text { Wawancara } \\
\text { - } & \text { Pitcher and Preikshot } \\
& (2001) * \text { dimodifikasi }\end{array}$ \\
\hline $\begin{array}{l}\text { 5. Hasil inventarisasi } \\
\text { pemanfaatan hutan } \\
\text { mangrove }\end{array}$ & $\begin{array}{l}(0)=\text { tidak tersedia; } \\
(1)=\text { tersedia }\end{array}$ & $\begin{array}{ll}\text { - } & \text { Wawancara } \\
\text { - } & \text { Pattimahu (2010) }\end{array}$ \\
\hline 6. Keterlibatan stakeholders & $\begin{aligned}(0)= & \text { tidak melibatkan stakeholder } \\
(1)= & \text { melibatkan hanya beberapa } \\
& \text { stakeholder } \\
(2)= & \text { melibatkan berbagai stakeholder }\end{aligned}$ & $\begin{array}{ll}\text { - } & \text { Wawancara } \\
\text { - } & \text { Pattimahu (2010) }\end{array}$ \\
\hline $\begin{array}{l}\text { 7. Zonasi pemanfaatan lahan } \\
\text { mangrove }\end{array}$ & $\begin{array}{l}(0)=\text { tidak tersedia; } \\
(1)=\text { tersedia, tapi belum dipatuhi; } \\
(2)=\text { tersedia dan dipatuhi }\end{array}$ & $\begin{array}{ll}\text { - } & \text { Wawancara } \\
\text { - } & \text { Pattimahu (2010) }\end{array}$ \\
\hline
\end{tabular}




\begin{tabular}{|c|c|c|}
\hline $\begin{array}{c}\text { Dimensi dan Indikator } \\
\text { (Dimensions and Indicators) }\end{array}$ & Keterangan (Description) & $\begin{array}{c}\text { Acuan Penentuan Kriteria } \\
\text { (Determination Reference Criteria) }\end{array}$ \\
\hline \multicolumn{3}{|l|}{ Kelembagaan (Institutional) } \\
\hline $\begin{array}{l}\text { 1. Kebijakan dan perencanaan } \\
\text { pengelolaan hutan mangrove }\end{array}$ & $\begin{array}{l}(0)=\text { tidak ada; } \\
(1)=\text { ada, tetapi belum dilaksanakan; } \\
(2)=\text { ada dan dilaksanakan }\end{array}$ & $\begin{array}{ll}\text { - } & \text { Wawancara } \\
\text { - } & \text { Pattimahu (2010) }\end{array}$ \\
\hline $\begin{array}{l}\text { 2. Ketersediaan aturan dan } \\
\text { peran lembaga non-formal }\end{array}$ & $\begin{array}{l}(0)=\text { tidak ada; } \\
(1)=\text { ada, tapi tidak efektif; } \\
(2)=\text { ada dan efektif }\end{array}$ & - Wawancara \\
\hline $\begin{array}{l}\text { 3. Keterlibatan lembaga } \\
\text { masyarakat }\end{array}$ & $\begin{aligned}(0)= & \text { masyarakat dan lembaga } \\
& \text { masyarakat tidak terlibat; } \\
(1)= & \text { masyarakat dan lembaga terlibat } \\
& \text { tetapi hanya secara prosedural; } \\
(2)= & \text { Masyarakat dan lembaga } \\
& \text { masyarakat terlibat aktif dalam } \\
& \text { memberikan informasi, } \\
& \text { proses dan penentuan } \\
& \text { mekanisme pengawasan } \\
& \& \text { evaluasi }\end{aligned}$ & $\begin{array}{ll}\text { - } & \text { Wawancara } \\
\text { - } & \text { Santoso (2012) }\end{array}$ \\
\hline $\begin{array}{l}\text { 4. Koordinasi antar lembaga } \\
\text { atau stakeholders }\end{array}$ & $\begin{array}{l}(0)=\text { tidak pernah dilaksanakan; } \\
(1)=\text { jarang dilaksanakan; } \\
(2)=\text { sekali dilaksanakan }\end{array}$ & $\begin{array}{ll}\text { - } & \text { Wawancara } \\
\text { - } & \text { Pattimahu }(2010)\end{array}$ \\
\hline $\begin{array}{l}\text { 5. Ketersediaan penyuluh atau } \\
\text { petugas lapangan }\end{array}$ & $\begin{array}{l}(0)=\text { tidak ada } \\
(1)=\text { ada, tetapi tidak berjalan efektif; } \\
(2)=\text { ada dan berjalan efektif }\end{array}$ & - Wawancara \\
\hline $\begin{array}{l}\text { 6. Kepatuhan terhadap aturan } \\
\text { pengelolaan }\end{array}$ & $\begin{aligned}(0)= & \text { rendah }(>5 \text { informasi } \\
& \text { pelanggaran }) \\
(1)= & \text { sedang }(2-4 \text { informasi } \\
& \text { pelanggaran }) \\
(2)= & \text { tinggi }(<5 \text { informasi } \\
& \text { pelanggaran })\end{aligned}$ & $\begin{array}{ll}\text { - } & \text { Wawancara } \\
\text { - } & \text { Theresia et al. (2015) }\end{array}$ \\
\hline $\begin{array}{l}\text { 7. Pemberian sanksi bagi } \\
\text { pelanggar }\end{array}$ & $\begin{aligned}(0)= & \text { tidak diimplementasikan; } \\
(1)= & \text { diimplementasikan, tetapi tidak } \\
& \text { efektif; } \\
(2)= & \text { diimplementasikan dan efektif }\end{aligned}$ & - Wawancara \\
\hline 8. Pemantauan dan pengawasan & $\begin{aligned}(0)= & \text { tidak ada pengawasan dan } \\
& \text { pemantauan; } \\
(1)= & \text { kurangnya pengawasan dan } \\
& \text { pemantauan } \\
(2)= & \text { selalu dipantau dan diawasi }\end{aligned}$ & - Wawancara \\
\hline
\end{tabular}

Sumber (Source): Muhsimin (2018) 